Highlights of Astronomy, Vol. 13

International Astronomical Union, 2003

O. Engvold, ed.

\title{
Pre-service Astronomy Education of Teachers
}

\author{
Mary Kay Hemenway \\ The University of Texas, Austin TX USA \\ E-mail: marykay@astro.as.utexas.edu
}

There is little research on elementary/secondary teacher preparation. Few teachers are called upon to teach astronomy specifically, or their astronomy teaching is peripheral to their main interest (e.g., general science at lower levels or physics at higher levels). Statistics indicate that large increases in student populations are expected throughout the world. "In 1997, 1.2 billion students were enrolled in schools around the world. Of these students, 668 million were in elementary-level programs, 398 million were in secondary programs, and 88 million were in higher education programs." (Digest, 2002) These figures included large increases from the 1990 figures, e.g. 38\% increase in secondary education and $68 \%$ in higher education for Africa, as opportunities to obtain an education and population both grew. (Digest, tables 395 and 412).

In spite of these increases in numbers of students attending school, it is unlikely that many are being taught astronomy by a teacher who has had any formal instruction in astronomy within their own teacher preparation program. Increases in students attending post-secondary institutions may translate into increases in students being introduced to astronomy through a survey course, but few preparing to be teachers are required to take a specific course in astronomy, even when astronomy specifically occurs in the curriculum. A survey of astronomers from fifteen countries showed that even in countries where astronomy is part of the national curriculum, it is not a required course for teacher certification. Some elementary school level teachers obtain some astronomy preparation in other courses, such as science methods or geography (earth-sun relations). Most of astronomy, including the topics that most interest the general public, is virtually ignored in teacher preparation programs.

In the past twenty years, education policy makers have pushed teacher preparation programs to increase the fraction of time that potential teachers study science and math compared with the time spent on "educational methods." In the last ten years, many countries have produced national or regional standards for teaching science. One example is the US National Science Education Standards (1996) with its vision for content and pedagogy. These standards provide expectations for all citizens, not just those planning technological careers. New standards challenge those who prepare candidates as teachers with their new expectations for professional development, both during the pre-service phase and following certification.

There are many issues surrounding teacher-preparation beyond content standards. For example, potential teachers who hold a degree, and often have many years of work experience, may obtain "alternative" teaching certification through training programs rather than a college or university course. Stoddart \& Floden (1995) showed that although current alternative routes may not sig- 
nificantly improve teacher learning, they are deemed to be no worse than many university-based teacher preparation programs. The argument of the importance of education preparation versus subject matter preparation was studied by Hashweh (1997) who showed that "the influence of teachers' prior subjectmatter knowledge was evident in their modifications of textbook subject-matter content and through their use of explanatory representations." It was especially noted in their content organization during instruction. Those with minimal knowledge followed the textbook closely (in content and structure) and neither added or deleted concepts. Those with a better background were likely to ask higher-order questions. For elementary school teachers, Coble \& Koballa (1996) believed that "science content is the centerpiece of science teacher preparation at all levels," although the average number of science courses for a potential teacher totaled 8.5 credit hour (each credit hour is about 15 classroom hours of instruction), mostly of survey courses that may not emphasize the inquiry techniques mandated by new education standards. Hanushek (1986) claimed that advanced degrees have not been found to improve teacher effectiveness, while the contribution of experience appears weak, at best, and limited to the first few years of teaching

In conclusion, there are no easy answers to preparing future teachers in astronomy, but it is a task worth doing. Astronomers are challenged to improve the K-12 educational system by working with the educational/political system to include astronomy in the curriculum, to forge connections with Education departments to influence their curriculum, to include topics found in the schools curriculum in their own college/university courses (which means being knowledgeable about what is in the curriculum). When the opportunity arises, astronomers should participate in editing/writing textbooks and offering professional development opportunities for teachers.

\section{References}

Coble, Charles R. and Thomas R. Koballa, Jr. 1996, "Science Education", Handbook of Research on Teacher Education, second ed., John Sikula (editor), Macmillan Library Reference, pp459-484

Hanushek, Eric A. 1986, "The Economics of Schooling: Production and Efficiency in Public Schools", Journal of Economic Literature 24(3) pp1141-1177

Hashweh, Marher Z. 1997, "Effects of Subject-Matter Knowledge in the Teaching of Biology and Physics", Teacher and Teacher Education 3(2), pp109-120

National Science Education Standards 1996, National Academy Press, http://www.nap.edu/readingroom/books/nses/html/

Stoddart, T. and R. E. Floden 1995, "Traditional and alternative routes to teacher certification: Issues, assumptions, and misconceptions". Issue paper 95-2. National Center for Research on Teacher Learning, Michigan State University. (ERIC Reproduction Service No. ED383697) as quoted by Carol Newman and Kay Thomas http://www.aaesa.org/Pubs/99perspect/altern_teacher_certif.html

U.S. Department of Education, Institute of Education Sciences NCES 2003-060 Digest of Education Statistics 2002, published 2003. 